\title{
Expression of the gene encoding oxalate decarboxylase from Bacillus subtilis and characterization of the recombinant enzyme
}

\author{
Eunhye Lee ${ }^{1+}$, Byong Chang Jeong ${ }^{2 \dagger}$, Yong Hyun Park ${ }^{3}$ and Hyeon Hoe Kim ${ }^{4 *}$
}

\begin{abstract}
Background: The concentration of urinary oxalate is more influential to the formation of calcium oxalate urolithiasis than is urinary calcium concentration. YvrK gene encodes a $43 \mathrm{KD}$-sized oxalate decarboxylase. We previously developed the recombinant Escherichia coli (E. coli) expressing Yvrk gene from Bacillus subtilis and named it as $p B y$. The aim of this study was to purify the recombinant oxalate decarboxylase overexpressed in $E$. coli and evaluate the oxalate-degrading activity of the purified enzyme.
\end{abstract}

Results: The oxalate-degrading activity of $p B y$ was highest when cultured at $\mathrm{pH} 5$. The activity of purified oxalate decarboxylase was determined after incubation with sodium oxalate and the optimal pH and temperature of oxalate decarboxylase were determined. Purified oxalate decarboxylase degraded more than $50 \%$ of oxalate when incubated with $\mathrm{MnCl}_{2}$ and sodium oxalate in atmospheric $\mathrm{O}_{2}$. The optimal $\mathrm{pH}$ of recombinant oxalate decarboxylase was 5 and the optimal temperature was $28^{\circ} \mathrm{C}$. Eight-week-old Sprague-Dawley male rats were used as a transient hyperoxaluric rat model. Suprapubic catheter was inserted into the bladder of each rat and urine was collected hourly before and 3 hours after oral oxalate intake in the absence and presence of homogenates of $p B y$ and non-recombinant $E$. coli as the control. After the oral intake of sodium oxalate, the concentration of oxalate in urine increased exponentially for 3 hours. The oxalate concentration in urine was decreased significantly by pBy homogenates compared to control.

Conclusions: We constructed the recombinant E. coli expressing YvrK gene and purified the recombinant oxalate decarboxylase successfully. Purified recombinant oxalate decarboxylase, as well as recombinant E. coli named pBy, showed the oxalate-degrading activity in in vitro and in vivo model.

Keywords: Oxalate, Yvrk, Bacillus subtilis

\section{Background}

Studies of the pathophysiology of urinary stones have focused on oxalate, since the concentration of urinary oxalate is more influential to the formation of calcium oxalate urolithiasis than is urinary calcium concentration [1]. Oxalate is the end product of a metabolic process; the compound is excreted into the urine. The majority of urinary oxalate is derived from the endogenous metabolism of glycine, glyoxylate, and ascorbic acid, and $40-50 \%$ is

\footnotetext{
* Correspondence: hhkim@snu.ac.kr

${ }^{\dagger}$ Equal contributors

${ }^{4}$ Department of Urology, Seoul National University College of Medicine and Clinical Research Institute, 28 Yeongeon-dong, Jongno-gu, Seoul 110-744, Korea

Full list of author information is available at the end of the article
}

derived from oral ingestion [2]. Hyperoxaluria is induced by the increased production of oxalate through an abnormal endogenous metabolism or by elevated intestinal absorption of oxalate [3,4]. Practically, it is difficult to control the endogenous metabolism of oxalate compared to the intestinal absorption of oxalate and some studies have sought to reduce intestinal absorption of oxalate.

Oxalobacter formigenes is an oxalate degrading bacterium colonizing the gastrointestinal tract of vertebrates including humans. The bacterium has a symbiotic relationship with its host by regulating oxalic acid absorption in the intestine and oxalate levels in plasma and urine $[5,6]$. Decreased intestinal colonization of $O$. formigenes has been reported in recurrent calcium oxalate stone formers and patients with enteric hyperoxaluria $[7,8]$. The absence 
of $O$. formigenes has been proposed as a risk factor for urolithiasis. However, O. formigenes is difficult to culture and isolate, and has complex pathways of oxalate degradation.

Recently, the entire DNA sequence of Bacillus subtilis (B. subtilis) has been determined, which revealed the existence of a gene designated $Y v r K$ gene that encodes a $43 \mathrm{KD}$-sized oxalate decarboxylase (OXDC). The OXDC degrades oxalate by a simple pathway $[9,10]$. Previously we produced a Yvrk gene-recombinant Escherichia coli (E. coli) designated $p B y$, which expresses OXDC, and evaluated oxalate-degrading activity of the bacteria [11]. The aim of the present study was to purify the recombinant OXDC and evaluate the oxalate-degrading activity of purified OXDC, with the goal of developing a new treatment for hyperoxaluria in urinary stone patients.

\section{Methods}

\section{Production of Yvrk-recombinant $E$. coli}

The Yvrk gene-recombinant E. coli was produced as described previously [11]. B. subtilis strain 128 obtained from the Korean Gene Bank was cultured for 24 hours in Luria-Bertani (LB) broth (Difco, USA) in an aerobic environment of $95 \% \mathrm{O}_{2} / 5 \% \mathrm{CO}_{2}$ and temperature of $37^{\circ} \mathrm{C}$. Cells were recovered by centrifugation at $5,000 \times \mathrm{g}$ at $4^{\circ} \mathrm{C}$ for 15 minutes. DNA was extracted from the cell pellet using a QIAamp DNA mini kit (Qiagen, USA).

The open reading frames and associated ribosome binding sites of B. subtilis 168 YvrK (GenBank $^{\mathrm{TM}}$ accession no. 2832786) were amplified by polymerase chain reaction (PCR) using genomic DNA with the following oligonucleotides (shown 5'-3'): Yvrk-F, ATGAAAAAAC AAAATG ACAT TCCG and Yvrk-R, TTTACTG CATTTCTTTT TCACTAC. The PCR products containing YvrK were digested with $\mathrm{NcoI}$ and SalI. The optimal reaction profile proved to be $94^{\circ} \mathrm{C}$ for 5 minutes, followed by 30 cycles of $94^{\circ} \mathrm{C}$ for 30 seconds for denaturation, $58^{\circ} \mathrm{C}$ for 30 seconds and $72^{\circ} \mathrm{C}$ for 30 seconds for annealing, and $72^{\circ} \mathrm{C}$ for 5 minute for primer extension. The PCR products were separated by gel electrophoresis in $2 \%$ agarose containing ethidium bromide, illuminated with ultraviolet light, and photographed for documentation.

The cloned Yvrk DNA segment was inserted into a pBAD/gIII-A vector containing a histidine tag. The DNA sequencing of the Yvrk-recombinant vector was done using an automated DNA sequencer (ABI Prism, USA). The recombinant vector was transfected to non-pathogenic TOP 10 E. coli with a heat shock method involving $42^{\circ} \mathrm{C}$ for 90 seconds followed by $4^{\circ} \mathrm{C}$ for 10 minutes. The recombinant $E$. coli were cultured and selected in LB agar including ampicillin $(100 \mu \mathrm{g} / \mathrm{ml})$ at $37^{\circ} \mathrm{C}$ and $95 \%$ $\mathrm{O}_{2} / 5 \% \mathrm{CO}_{2}$ for 24 hours.

$p B y$ was grown at $37^{\circ} \mathrm{C}$ until an $\mathrm{OD}_{600}$ value of 0.5 with shaking. After heat-shocking at $42^{\circ} \mathrm{C}$ for 2 minutes
[12], $5 \mu \mathrm{l} / \mathrm{ml}$ of serial dilution of L-arabinose (Invitrogen, USA; $0.02 \%, 0.2 \%, 2 \%, 20 \%$ ) and $5 \mathrm{mM} \mathrm{MnCl}_{2}$ (SigmaAldrich, USA) were added. The cells were incubated at $37^{\circ} \mathrm{C}$ for 6 hours with shaking and harvested by centrifugation $\left(13000 \mathrm{rpm}, 10\right.$ minutes, $\left.4^{\circ} \mathrm{C}\right)$ and stored at $-80^{\circ} \mathrm{C}$. Cells containing the empty vector were compared as negative control. The cell pellet was mixed with sodium dodecyl sulfate (SDS) sample buffer and visualized by $0.1 \%$ Brilliant Blue R (Sigma-Aldrich, USA) staining after separating by SDS-polyacrylamide gel electrophoresis (SDS-PAGE).

\section{Purification and characterization of recombinant enzyme}

$p B y$ cells were grown at $37^{\circ} \mathrm{C}$ until an $\mathrm{OD}_{600}$ value of 0.3 with shaking. After heat-shocking at $42^{\circ} \mathrm{C}$ for 2 minutes, $5 \mathrm{\mu l} / \mathrm{ml}$ of $2 \% \mathrm{~L}$-arabinose and $5 \mathrm{mM} \mathrm{MnCl}_{2}$ were added. To increase the solubility of OXDC, the cells were incubated at $28^{\circ} \mathrm{C}$ for 24 hours and centrifuged. The cell pellet was stored at $-80^{\circ} \mathrm{C}$.

For purification under native conditions the cells pellet was thawed for 15 minutes and suspended in lysis buffer (50 mM NaH${ }_{2} \mathrm{PO}_{4}, 300 \mathrm{mM} \mathrm{NaCl}, 10 \mathrm{mM}$ imidazole, $\mathrm{pH}$ 8.0). Cells were incubated on ice for 30 minutes, after which lysozyme was added to $1 \mathrm{mg} / \mathrm{ml}$. The solution was sonicated on ice and the cell lysate was centrifuged at $10,000 \times \mathrm{g}$ for $30 \mathrm{~min}$ at $4^{\circ} \mathrm{C}$. Ni-NTA Superflow (Qiagen, USA) was added to cleared lysate and mixed gently by shaking (200 rpm on a rotary shaker) at $4^{\circ} \mathrm{C}$ for 60 minutes. The lysate-Ni-NTA mixture was loaded into a column (BioRad, USA) and washed twice with wash buffer $\left(50 \mathrm{mM} \mathrm{NaH} \mathrm{PO}_{4}, 300 \mathrm{mM} \mathrm{NaCl}, 20 \mathrm{mM}\right.$ imidazole, $\mathrm{pH} 8.0$ ), and the protein was eluted with elution buffer $\left(50 \mathrm{mM} \mathrm{NaH} \mathrm{PO}_{4}, 300 \mathrm{mM} \mathrm{NaCl}, 250 \mathrm{mM}\right.$

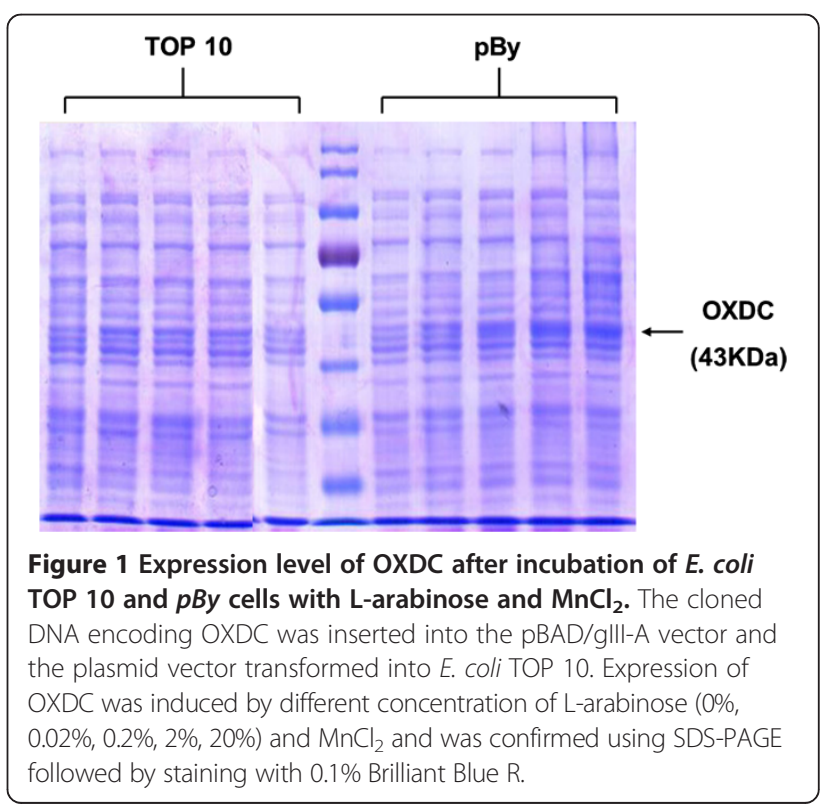


imidazole, $\mathrm{pH}$ 8.0). The cell lysate, wash and elutes were mixed with SDS sample buffer and evaluated by SDS-PAGE.

To determine the optimal $\mathrm{pH}$ and temperature, purified OXDC or PBS in $\mathrm{pH} 5, \mathrm{pH} 6$, or $\mathrm{pH} 7$ was incubated with $5 \mathrm{mM} \mathrm{MnCl} 2$ and $1.5 \mathrm{mM}$ sodium oxalate for 24 hours at $10^{\circ} \mathrm{C}, 20^{\circ} \mathrm{C}, 28^{\circ} \mathrm{C}, 37^{\circ} \mathrm{C}, 42^{\circ} \mathrm{C}, 60^{\circ} \mathrm{C}$, or $70^{\circ} \mathrm{C}$ in atmospheric $\mathrm{O}_{2}$. The oxalate-degrading activity of purified OXDC protein was measured using an oxalate kit (Trinity Biotech, USA).

\section{In vivo oxalate-degrading activity}

This study was approved by the Institutional Animal Care and Use Committee at Seoul National University
Hospital Biomedical Research Institute. A transient hyperoxaluric rat model was established using 8-week-old Sprague-Dawley male rats [13]. Rats were anesthetized with an intramuscular injection of an 8:2 mixture of ketamine (Yuhan, Korea) and rompun (Bayer, Germany). A midline laparotomy was performed and a p10 tube was inserted into the bladder. Urine was collected hourly through the p10 tube before and until 3 hours after oral oxalate intake together with homogenates of $p B y$ and TOP 10 E. coli (control). For oral oxalate intake, $0.5 \mathrm{ml}$ of $1 \mathrm{mM}$ sodium oxalate solution and $0.5 \mathrm{ml}$ of $p B y$ homogenates was administered through gastric gavage. Oxalate concentration in the hourly-collected urine was measured by a commercial oxalate kit.

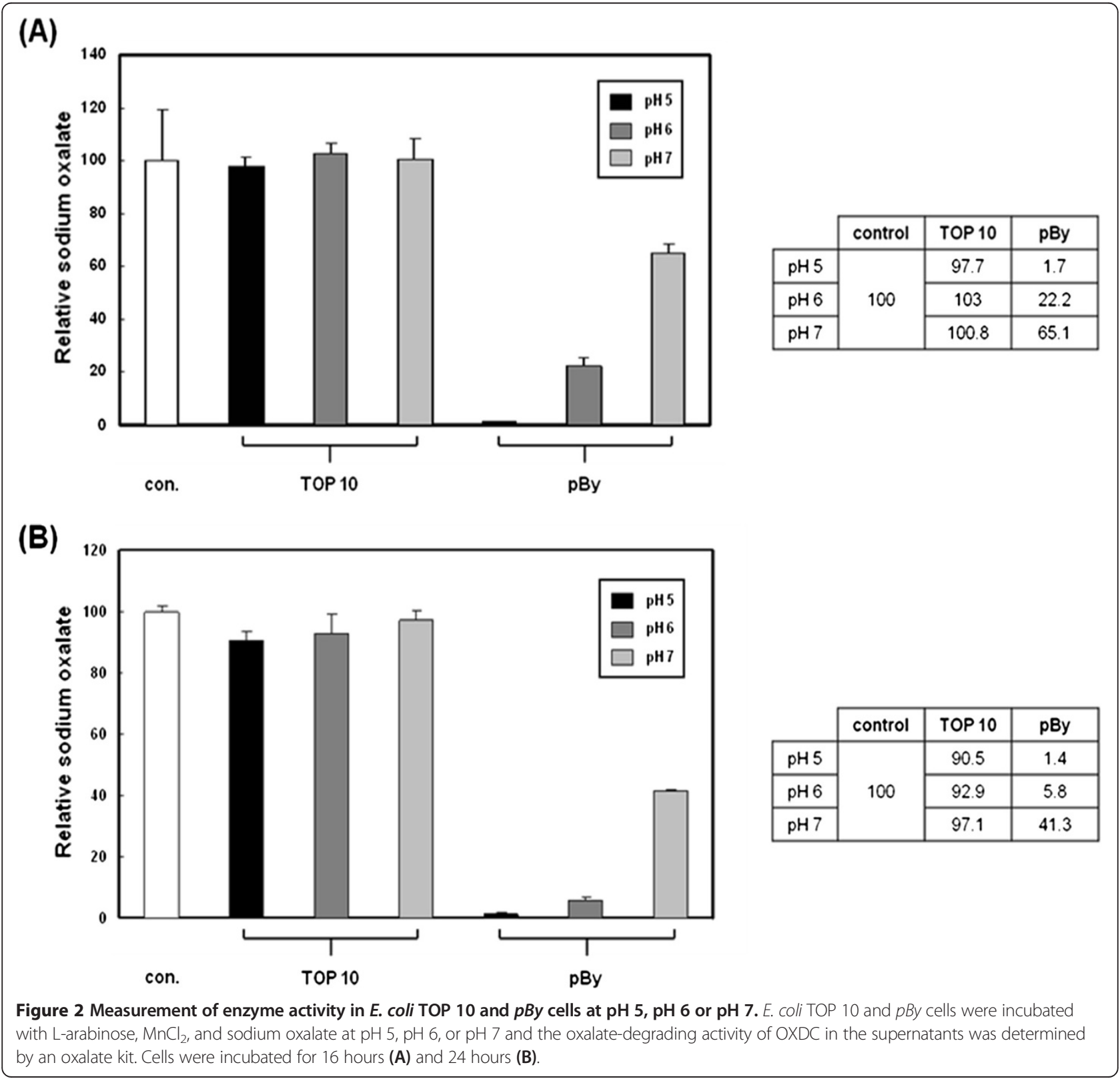




\section{Results and discussion}

\section{Production of Yvrk-recombinant $E$. coli}

As we previously reported [11], $1.2 \mathrm{~kb}$ sized Yvrk gene was cloned from genomic DNA of B. subtilis by PCR. The Yvrk gene DNA were inserted into the pBAD/gIII-A vector. Automated DNA sequencing identified the same DNA sequence of Yvrk gene-recombinant pBAD/gIII-A vector to that of the Yvrk gene registered in National Center for Biotechnology Information. Figure 1 showed that the expression of OXDC was induced by treatment with L-arabinose in a dose-dependent manner. E. coli TOP 10 or $p B y$ cells were grown in $\mathrm{pH} 5, \mathrm{pH} 6$ or $\mathrm{pH} 7$ $\mathrm{LB}$ medium. When the cultures reached $\mathrm{OD}_{600}$ of 0.05 , they were heat-shocked and incubated with L-arabinose, $\mathrm{MnCl}_{2}$ and sodium oxalate for 16 hours or 24 hours. LB medium was also incubated and used as control. The oxalate-degrading activity of $p B y$ was determined by measurement of remaining oxalate. After incubation, amount of oxalate was not changed in E. coli TOP 10 at pH 5,6 or 7 (Figure 2A). However, $p B y$ showed oxalate-degrading activity which was dependent on $\mathrm{pH}$ and high in acidic condition (Figure 2B).

\section{Purification and characterization of recombinant enzyme}

The protein obtained as the purified enzyme was analyzed by SDS-PAGE. The molecular mass was $43 \mathrm{kDa}$ (Figure 3). We found trace amounts of additional protein bands in this lane that might be partly host proteins and partly OXDC degradation products. To measure the activity

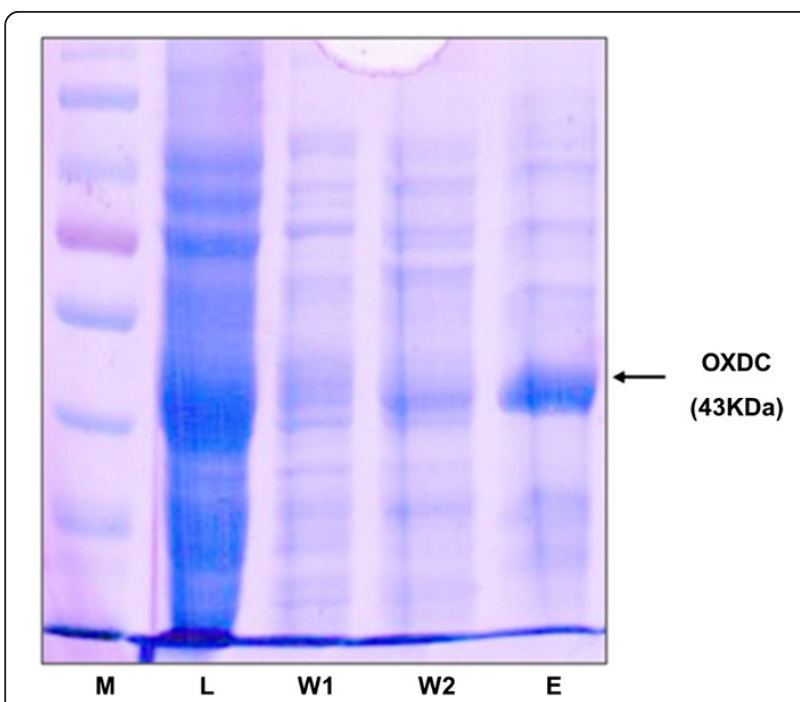

Figure 3 Purification of recombinant OXDC by affinity chromatography and evaluation of the purity of recombinant proteins by SDS-PAGE. The $p B y$ cells were incubated with $\mathrm{L}$-arabinose and $\mathrm{MnCl}_{2}$. After 6 hours of incubation, cells were harvested and purified using the Ni-NTA Superflow technique. The purity of recombinant proteins was determined by SDS-PAGE. M: markers; L: lysates; W1 \& W2: first and second wash; E: elutes. of purified enzyme, purified OXDC or PBS at pH 5 was incubated with $\mathrm{MnCl}_{2}$ and sodium oxalate for 5 minutes or 24 hours at room temperature in atmospheric $\mathrm{O}_{2}$. After incubation, oxalate-degrading activity of enzyme was measured. As shown in Figure 4A, oxalate was slightly degraded by OXDC 5 minutes later. After incubation for 24 hours, significantly reduced oxalate was evident (Figure 4B). To characterize the OXDC, specific activity of the purified protein from $p B y$ was measured at $\mathrm{pH} 5$, 6 or 7 and various temperatures after incubation with $\mathrm{MnCl}_{2}$ and sodium oxalate for 24 hours. The optimal $\mathrm{pH}$ of OXDC was determined over the $\mathrm{pH}$ range of 5 to 7 , in $\mathrm{pH} 1$ intervals. At $\mathrm{pH} 5$, the oxalate-degrading activity was the highest at $28^{\circ} \mathrm{C}$ and $37^{\circ} \mathrm{C}$ and the more it was incubated in acidic LB medium, the higher enzyme activity was (Figure 5A, B). At other temperatures, measurement of enzyme activity at pH 5-7 also was found similar results (data not shown). The optimal temperature of OXDC was investigated over the temperature range $10^{\circ} \mathrm{C}$ to $70^{\circ} \mathrm{C}$. The highest activities at $\mathrm{pH} 5$ (Figure 5C), pH 6 and $\mathrm{pH} 7$ (data not shown) were at $28^{\circ} \mathrm{C}$.

\section{In vivo oxalate-degrading activity}

pBy homogenates reduced urinary oxalate concentration significantly compared to E.coli TOP 10 in the transient hyperoxaluric rat model. The urinary oxalate concentration increased linearly at 1,2 , and 3 hours after gastric loading of $1 \mathrm{mM}$ of sodium oxalate into rats (Figure 6).

\section{Discussion}

Several human diseases have been linked to the excessive excretion of urinary oxalate. Mild forms of hyperoxaluria can lead to kidney stones. Kidney stone formation is a common urological disorder in the U.S. of nearly $13 \%$ in men and $7 \%$ in women. Recurrence of stone formation is common [14]. Larger amounts of oxalate in the urine can be caused by over-absorption of oxalic acid due to intestinal diseases. O. formigenes, degrades oxalate and maintains an important symbiotic relationship with its hosts by regulating oxalic acid absorption in the intestine [5].

B. subtilis is a Gram-positive, bacterium commonly found in soil. B. subtilis is rod-shaped endospore forming bacterium, which can tolerate extreme environment. A whole genome analysis of $B$. subtilis has revealed approximately 4,100 genes. Of these, 192 are indispensable and 79 are essential. B. subtilis harbors four bicupin-encoding genes: YvrK, YoaN, YxaG and YwfC. YvrK and YoaN encode OXDC and $Y x a G$ encodes quercetin dioxygenase [10]. The Yvrk gene has been identified in B. subtilis [9] and the produced OXDC degrades oxalate in a simple pathway.

However, B. subtilis does not express the Yvrk gene during growth in normal conditions and does not use 


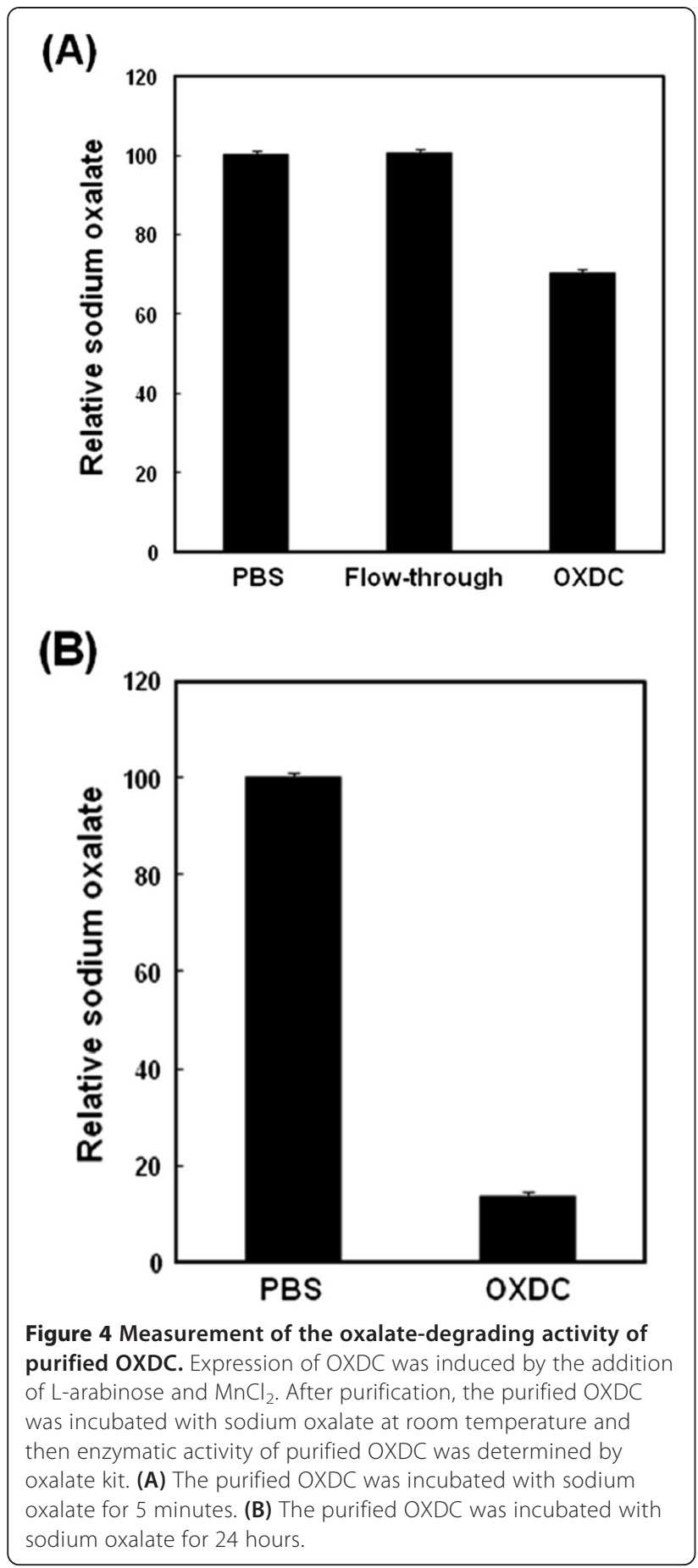

oxalate as a metabolic source, unlike $O$. formigenes, which degrades oxalate by a metabolism to maintain its life. B. subtilis expresses Yvrk in the acidic condition when it forms endospores. Therefore, we did not manage $B$. subtilis directly in the experiment to control oxalate and produced Yvrk-recombinant E. coli ( $p B y)$ capable of degrading oxalate [11]. Our results show that YvrK gene from $B$. subtilis was successfully overexpressed in

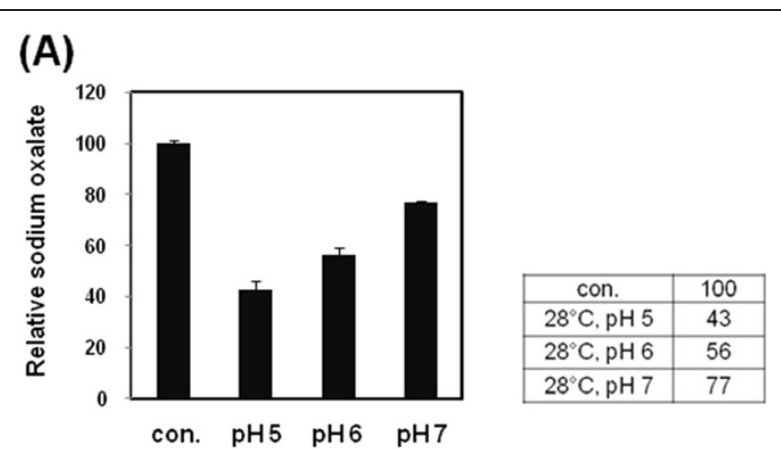

(B)

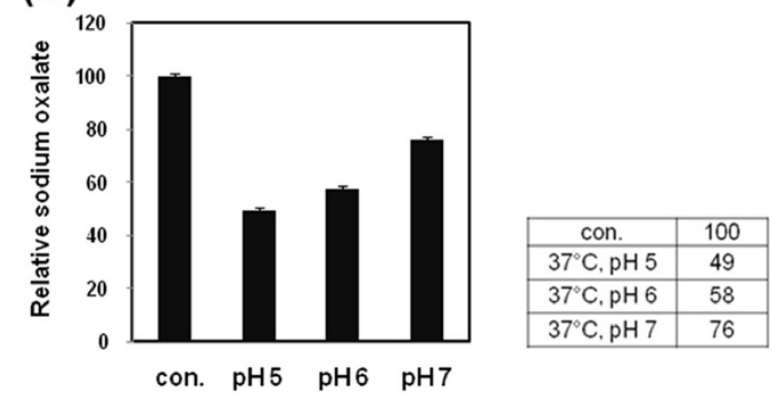

(C)

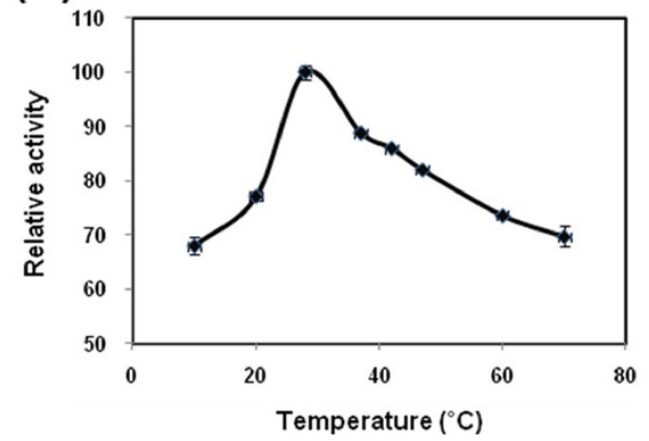

Figure 5 Effect of $\mathrm{pH}$ and temperature on the oxalate-degrading activity. Purified OXDC was incubated with oxalate at $\mathrm{pH}$ 5, 6 or 7 and enzyme activity of purified OXDC was determined by oxalate kit to investigate the optimal $\mathrm{pH}$ and temperature. Enzyme activity of purified OXDC ( $\mathrm{pH} 5, \mathrm{pH} 6$ or $\mathrm{pH} 7$ ) was measured at $28^{\circ} \mathrm{C}(\mathbf{A})$ or $37^{\circ} \mathrm{C}$ (B). To investigate the optimal temperature, enzyme activity of purified OXDC at pH 5 was determined at $10^{\circ} \mathrm{C}, 20^{\circ} \mathrm{C}, 28^{\circ} \mathrm{C}, 37^{\circ} \mathrm{C}, 42^{\circ} \mathrm{C}, 60^{\circ} \mathrm{C}$, or $70^{\circ} \mathrm{C}(\mathrm{C})$

E. coli when $p B y$ was incubated in the presence of manganese and oxygen, and the purified recombinant OXDC, as well as recombinant E. coli named $p B y$, had the oxalate-degrading activity. These results suggest that recombinant OXDC may be used for the treatment of human hyperoxaluria and prevent calcium oxalate nephrocalcinosis and urolithiasis.

The oxalate-degrading activity of $p B y$ and recombinant OXDC in acidic conditions may be limited clinically because the main oxalate absorbing regions in humans are known the ileum and colon, whose $\mathrm{pH}$ is about 7 . In this 


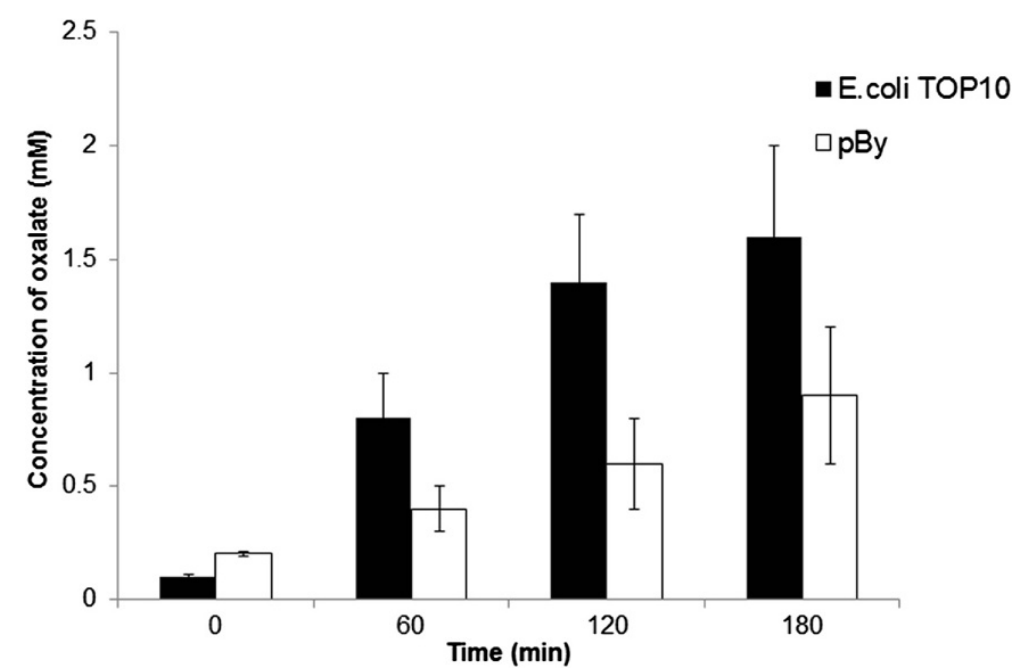

Figure 6 In vivo functional assay of $p B y$ homogenate using hyperoxaluric rat model. The oral intake of $p B y$ homogenate reduced hyperoxaluria compared to control (E coli TOP 10).

study, the capacity of $p B y$ and the purified recombinant OXDC to degrade oxalate was reduced at near-neutral. However, some studies reported that stomach is also one of main places for oxalate absorption to be absorbed in human above ileum and colon [15-17]. One study evaluated six adult patients on permanent gastric tube feeding for various reasons, and reported a linear increase in the urinary oxalate excretion with increased gastric loading time [17]. The authors concluded that the stomach is not only just another oxalate absorption site but seems to be the critical site for intestinal oxalate absorption in an intact gastrointestinal tract.

We developed a transient hyperoxaluric rat model duplicating the performance of this prior study. Since we use rat models, we collected urine using a suprapubic catheter. The urinary oxalate concentration increased linearly at 1,2 , and 3 hours after gastric loading of oxalate into rats, similar to the previous findings with human patients [17]. When $p B y$ homogenate was fed together with oxalate loading, the urinary oxalate concentration decreased compared to control. The results indicate that $p B y$ homogenate acts in the stomach of rats and degrades oxalate in vivo. Although using $p B y$ homogenate for in vivo functional assay is acceptable for providing preliminary evidence, it is probably more preferred to use purified enzyme, since purified enzyme will be free from contaminants and antigens of host cells, which otherwise may be present in the crude extract. Our next plan is to reveal that purified recombinant OXDC can reduce urinary oxalate concentration and inhibit stone formation in stone-forming rat models.

\section{Conclusions}

In conclusion, we constructed a recombinant E. coli expressing the $Y v r K$ gene and purified the recombinant
OXDC successfully. The purified enzyme, as well as the recombinant $E$. coli named $p B y$, showed the oxalatedegrading activity in in vitro and in vivo model. These data suggest that recombinant OXDC will provide a solution in the treatment of calcium oxalate stone and hyperoxaluria, which presently lack treatment modalities.

\section{Abbreviations}

OXDC: Oxalate decarboxylase.

\section{Competing interests}

I certify that the authors' had no competing interest, including specific financial interests, relationships, or affiliations relevant to the subject matter or materials discussed in the manuscript (e.g., employment/affiliation, grants or funding, consultancies, honoraria, stock ownership or options, expert testimony, royalties, or patents filed, received, or pending).

\section{Authors' contributions}

Substantial contributions to conception and design: EL, HHK. Data acquisition: YHP, EL. Data analysis and interpretation: EL, BCJ, Drafting the manuscript: EL, BCJ. Critical revision of the manuscript for scientific and factual content: YHP, HHK. Statistical analysis: YHP. Supervision: HHK. All authors read and approved the final manuscript.

\section{Acknowledgement}

This research was supported by a grant of the Korea Healthcare technology R\&D Project, Ministry of Health \& Welfare, Republic of Korea (A080335) and a Research Foundation Grant funded by the Seoul National University Hospital (03-2006-0010).

\section{Author details}

${ }^{1}$ Clinical Research Institute, Seoul National University Hospital, Seoul, Korea. ${ }^{2}$ Department of Urology, Samsung Medical Center, Sungkyunkwan University School of Medicine, Seoul, Korea. ${ }^{3}$ Department of Urology, The Catholic University of Korea, Seoul St. Mary's Hospital, Seoul, Korea. ${ }^{4}$ Department of Urology, Seoul National University College of Medicine and Clinical Research Institute, 28 Yeongeon-dong, Jongno-gu, Seoul 110-744, Korea.

Received: 17 February 2014 Accepted: 31 July 2014

Published: 3 September 2014 


\section{References}

1. Finlayson B, Khan SR, Hackett RL: Mechanisms of stone formation-an overview. Scan Electron Microsc 1984, (Pt 3):1419-1425.

2. Holmes RP, Goodman HO, Assimos DG: Contribution of dietary oxalate to urinary oxalate excretion. Kidney Int 2001, 59:270-276.

3. Chadwick VS, Modha K, Dowling RH: Mechanism for hyperoxaluria in patients with ileal dysfunction. N Engl J Med 1973, 289:172-176.

4. Smith LH, Fromm H, Hofmann AF: Acquired hyperoxaluria, nephrolithiasis, and intestinal disease. Description of a syndrome. N Engl J Med 1972, 286:1371-1375.

5. Allison MJ, Dawson KA, Mayberry WR, Foss JG: Oxalobacter formigenes gen. nov., sp. nov.: oxalate-degrading anaerobes that inhabit the gastrointestinal tract. Arch Microbiol 1985, 141:1-7.

6. Kleinschmidt K, Mahlmann A, Hautmann R: Microbial degradation of dietary oxalate in the human gut and urinary oxalate concentrations in patients with calcium oxalate urolithiasis and control persons. Investig Urol 1994, 5:222-224.

7. Kleinschmidt K, Mahlmann A, Hautmann R: Anaerobic oxalate-degrading bacteria in the gut decrease faecal and urinary oxalate concentrations in stone formers. Urolithiasis 1993, 2:439-441.

8. Kwak C, Kim HK, Kim EC, Choi MS, Kim HH: Urinary oxalate levels and the enteric bacterium Oxalobacter formigenes in patients with calcium oxalate urolithiasis. Eur Urol 2003, 44:475-481.

9. Tanner A, Bornemann S: Bacillus subtilis YvrK is an acid-induced oxalate decarboxylase. J Bacteriol 2000, 182:5271-5273.

10. Tanner A, Bowater L, Fairhurst SA, Bornemann S: Oxalate decarboxylase requires manganese and dioxygen for activity. Overexpression and characterization of Bacillus subtilis YvrK and YoaN. J Biol Chem 2001, 276:43627-43634

11. Jeong BC, Park YH, Kim HH: Development of Yvrk gene-recombinant E. coli degrading oxalate. Korean J Urol 2009, 50:1022-1026.

12. Froger A, Hall JE: Transformation of plasmid DNA into E. coli using the heat shock method. J Vis Exp 2007, (6):253.

13. Sidhu H, Allison MJ, Chow JM, Clark A, Peck AB: Rapid reversal of hyperoxaluria in a rat model after probiotic administration of oxalobacter formigenes. J Urol 2001, 166:1487-1491.

14. Khan SR, Canales BK: Genetic basis of renal cellular dysfunction and the formation of kidney stones. Urol Res 2009, 37:169-180.

15. Chen Z, Ye Z, Zeng L, Yang W: Clinical investigation on gastric oxalate absorption. Chin Med J 2003, 116:1749-1751.

16. Jaeger $P$, Robertson WG: Role of dietary intake and intestinal absorption of oxalate in calcium stone formation. Nephron Physiol 2004, 98:64-71.

17. Hautmann RE: The stomach: a new and powerful oxalate absorption site in man. J Urol 1993, 149:1401-1404.

doi:10.1186/1756-0500-7-598

Cite this article as: Lee et al: Expression of the gene encoding oxalate decarboxylase from Bacillus subtilis and characterization of the recombinant enzyme. BMC Research Notes 2014 7:598.

\section{Submit your next manuscript to BioMed Central and take full advantage of:}

- Convenient online submission

- Thorough peer review

- No space constraints or color figure charges

- Immediate publication on acceptance

- Inclusion in PubMed, CAS, Scopus and Google Scholar

- Research which is freely available for redistribution 